OPEN ACCESS

Edited by:

Sandra Amor

VU University Medical

Center, Netherlands

Reviewed by: Maria Grazia Cifone,

University of L'Aquila, Italy

Seema TiwariWoodruff, University of California, Riverside,

United States

*Correspondence:

V. Wee Yong

vyong@ucalgary.ca

${ }^{\dagger}$ These authors share first authorship

Specialty section:

This article was submitted to

Multiple Sclerosis and

Neuroimmunology,

a section of the journal

Frontiers in Immunology

Received: 28 October 2019 Accepted: 03 February 2020

Published: 21 February 2020

Citation:

Sarkar S, Li Y, Mirzaei R, Rawji KS, Poon CC, Wang J, Kumar M, Bose $P$ and Yong WW (2020) Demeclocycline Reduces the Growth of Human Brain

Tumor-Initiating Cells: Direct Activity and Through Monocytes. Front. Immunol. 11:272.

doi: 10.3389/fimmu.2020.00272

\section{Demeclocycline Reduces the Growth of Human Brain Tumor-Initiating Cells: Direct Activity and Through Monocytes}

\author{
Susobhan Sarkar ${ }^{1,2+}$, Yibo $\mathrm{Li}^{1,2+}$, Reza Mirzaei ${ }^{1,2+}$, Khalil S. Rawji ${ }^{1,2}$, Candice C. Poon ${ }^{1,2}$, \\ Jianxiong Wang ${ }^{1,2}$, Mehul Kumar ${ }^{3,4}$, Pinaki Bose ${ }^{3,4}$ and V. Wee Yong ${ }^{1,2 *}$ \\ 1 Department of Clinical Neurosciences, The Hotchkiss Brain Institute and the Arnie Charbonneau Cancer Institute, University \\ of Calgary, Calgary, AB, Canada, ${ }^{2}$ Department of Oncology, The Hotchkiss Brain Institute and the Arnie Charbonneau \\ Cancer Institute, University of Calgary, Calgary, AB, Canada, ${ }^{3}$ Department of Biochemistry and Molecular Biology, The \\ Hotchkiss Brain Institute and the Arnie Charbonneau Cancer Institute, University of Calgary, Calgary, AB, Canada, \\ ${ }^{4}$ Department of Surgery, The Hotchkiss Brain Institute and the Arnie Charbonneau Cancer Institute, University of Calgary, \\ Calgary, $A B$, Canada
}

Myeloid cells that infiltrate into brain tumors are deactivated or exploited by the tumor cells. We previously demonstrated that compromised microglia, monocytes, and macrophages in malignant gliomas could be reactivated by amphotericin-B to contain the growth of brain tumorinitiating cells (BTICs). We identified meclocycline as another activator of microglia, so we sought to test whether its better-tolerated derivative, demeclocycline, also stimulates monocytes to restrict BTIC growth. Monocytes were selected for study as they would be exposed to demeclocycline in the circulation prior to entry into brain tumors to become macrophages. We found that demeclocycline increased the activity of monocytes in culture, as determined by tumor necrosis factor- $\alpha$ production and chemotactic capacity. The conditioned medium of demeclocycline-stimulated monocytes attenuated the growth of BTICs generated from human glioblastoma resections, as evaluated using neurosphere and alamarBlue assays, and cell counts. Demeclocycline also had direct effects in reducing BTIC growth. A global gene expression screen identified several genes, such as DNA damage inducible transcript 4, frizzled class receptor 5 and reactive oxygen species modulator 1, as potential regulators of demeclocycline-mediated BTIC growth reduction. Amongst several tetracycline derivatives, only demeclocycline directly reduced BTIC growth. In summary, we have identified demeclocycline as a novel inhibitor of the growth of BTICs, through direct effect and through indirect stimulation of monocytes. Demeclocycline is a candidate to reactivate compromised immune cells to improve the prognosis of patients with gliomas.

Keywords: glioma, innate immunity, monocytes, macrophages, microglia, stem cells 


\section{INTRODUCTION}

Malignant gliomas are brain tumors that arise from within the central nervous system (CNS). The most aggressive form, glioblastoma multiforme, has a dismal prognosis with a median survival of 15 months; $<10 \%$ of patients survive beyond 5 years $(1-3)$. The poor prognosis of malignant gliomas is attributed in part to the existence of glioma stem cells, also called brain tumorinitiating cells (BTICs) (4-9). BTICs are resistant to therapies as they continue to seed and form new tumor foci in the brain. BTICs have been shown to contribute to the tumourigenesis and recurrence of gliomas (10), particularly due to their high chemoand radio-resistance $(11,12)$.

Surrounding BTICs in situ are microglia, which are innate immune cells of the CNS and macrophages that have infiltrated as monocytes from the circulation (13-16). These cells are thought to be initially recruited to eradicate the tumor by stimulating apoptosis of glioma cells (17) and by secreting inflammatory factors that prevent glioma growth and invasiveness (18). However, glioma cells have been shown to induce an immunosuppressive phenotype that in turn enhances tumor growth. For example, glioma cells have been shown to secrete periostin, which selectively recruits macrophages with an immunosuppressive profile (19). Furthermore, interactions between glioma and macrophages/microglia can lead to promotion of tumor growth (20-22). These immune cells have been shown to enhance tumor CCL21 expression, which facilitates tumor immune escape (23). Notably, BTICs also interact with macrophages and microglia within the tumor microenvironment, inducing an immunosuppressive macrophage/microglia cell profile that leads to promotion of tumor invasion $(24,25)$. We made the discovery that microglia, monocytes, and macrophages derived from glioma patients are deficient in their capacity to reduce the growth of BTICs (26).

Based on the above discussion, activating or reprogramming immune cells may represent an approach to curb BTIC growth (27-29). Kees et al. (30) demonstrated that stimulation of microglia with toll-like receptor-3 agonist, poly(I:C), prior to co-culture with tumor cells promotes microglia tumouricidal activity in vitro. However, direct poly (I:C) treatment was ineffective in glioma patients (30).

A recent study has shown that manipulation of RNA regulator in tumor-associated microglia and macrophages stimulates antitumor immunity and reduces glioma growth (31). More recently, we found that the compromised monocyte, macrophages and microglia from patients with glioma could be reactivated by amphotericin B to reduce BTIC growth in culture and to prolong the lifespan of mice with intracranial patient-derived BTIC xenografts (26). Despite these promising results, amphotericin B may not find clinical utility in gliomas as it has significant acute and chronic toxic side effects ranging from hypoxia to nephrotoxicity (32).

We discovered the pro-activation capacity of amphotericin B on microglia during a screen of a 1,040-drug library (33). During that screen, we discovered another stimulator of the activity of microglia in culture, as measured by TNF- $\alpha$ production: meclocycline, a tetracycline antibiotic. Meclocycline has significant toxicity and is limited to topical use, but a derivative, demeclocycline, can be administered systemically (34) (www.drugs.com). Demeclocycline is used clinically as a prescription medication to treat susceptible bacterial infections, as well as off-label to manage chronic syndrome of inappropriate secretion of anti-diuretic hormone (SIADH).

Here, we have evaluated the effects of demeclocycline on BTIC growth either through direct mechanisms or indirectly through the stimulation of monocytes. We chose monocytes for study as systemic monocytes would be exposed to demeclocycline prior to their infiltration into brain tumors as macrophages to influence BTIC properties. Our results suggest the potential utility of demeclocycline in glioblastoma.

\section{MATERIALS AND METHODS \\ Isolation and Culture of Monocytes and Macrophages}

Human monocytes were isolated from the venous blood of adult healthy individuals as described elsewhere (26). Briefly, monocytes $(100,000$ cells/well/100 $\mu \mathrm{l})$ following isolation were plated in RPMI medium supplemented with $20 \%$ human serum in 96 well plates. After $24 \mathrm{~h}$, cells were switched to BTIC medium. Cells were transferred to BTIC medium an hour prior to treatment. Treatment involved administering each drug at different concentrations with or without LPS $(100 \mathrm{ng} / \mathrm{ml})$. Briefly, monocytes were treated with demeclocycline (10 or $1 \mu \mathrm{M})$ for $48 \mathrm{~h}$ in BTIC medium and conditioned media were collected. Bone marrow-derived macrophages (BMDM) were isolated from mice as described elsewhere (35). Unless otherwise stated, BMDM cells were plated at 30,000 cells in AIMV medium for collection of conditioned media (see below), or for assessment of their activity.

\section{Evaluation of Activity of Monocytes and Macrophages in Response to Demeclocycline Treatment}

We utilized the level of tumor necrosis factor- $\alpha$ (TNF$\alpha)$ as a first indicator of cellular activity. Following $24 \mathrm{~h}$ treatment with demeclocycline $(10 \mu \mathrm{M}$, Sigma) with or without IFN $\gamma(100 \mathrm{ng} / \mathrm{ml}) / \mathrm{IL}-1 \beta \quad(100 \mathrm{ng} / \mathrm{ml})$ (Peprotech) or LPS $(100 \mathrm{ng} / \mathrm{ml})$, the conditioned medium was collected for TNF- $\alpha$ ELISA following manufacturer's instructions (Life Technologies Invitrogen).

\section{Chemotaxis Assay}

Human monocytes were treated with demeclocycline $(10 \mu \mathrm{M})$. After $1 \mathrm{~h}$ of incubation at $37^{\circ} \mathrm{C}$ with $5 \% \mathrm{CO}_{2}$, IFN $\gamma(100 \mathrm{ng} / \mathrm{ml}) / \mathrm{IL}-1 \beta(100 \mathrm{ng} / \mathrm{ml})$ was added. After $24 \mathrm{~h}$, human monocytes were harvested and resuspended in RPMI 1640 media supplemented with $2 \%$ penicillin/streptomycin, $10 \%$ fetal bovine serum, L-glutamine, and $1 \mathrm{mM}$ sodium pyruvate. Two hundred thousand cells were plated onto the filters of $5 \mu \mathrm{m}$ pore size ChemoTx plates (NeuroProbe). Recombinant human CCL2 (Peprotech) $(10 \mathrm{ng} / \mathrm{ml})$ was diluted in supplemented RPMI 1640 media and $300 \mu \mathrm{l} /$ well was added into wells below 
the filter so as to provide a chemotactic stimulus. Two controls were used in this assay. The first control was medium only. The second one was chemokinetic control where the cells plated onto the filter contained the $10 \mathrm{ng} / \mathrm{ml}$ of CCL2 as in the underlying well. To obtain a standard curve, halving numbers of cells were plated ranging from 0 to 200,000 . Cells were incubated at $37^{\circ} \mathrm{C}$ in humidified air with $5 \% \mathrm{CO}_{2}$ for $16 \mathrm{~h}$. They were then washed off the top of the filter and the plate spun at 1,400 rpm for $10 \mathrm{~min}$ at room temperature. One hundred and fifty microliter of the media was discarded in the microplate and replaced with $15 \mu \mathrm{l}$ of alamarBlue ${ }^{\circledR}$ (Invitrogen). The plate was then placed at $37^{\circ} \mathrm{C}$ in humidified air with $5 \% \mathrm{CO}_{2}$ for $4 \mathrm{~h}$ and signal was read at $570 \mathrm{~nm}$. This assay was also conducted with mouse BMDM.

\section{Human Neuron Toxicity Assay}

Brain tissue from fetuses legally aborted at 15-20 weeks was used to isolate human neurons. The use of the brain cells was conducted with ethics approval from the University of Calgary human ethics committee. The neurons were isolated by removal of the meninges followed by mechanical dissociation of the tissue. Tissue was then digested in DNase $(6-8 \mathrm{~mL}$ of $1 \mathrm{mg} / \mathrm{mL}$; Roche), $4 \mathrm{~mL} 2.5 \%$ trypsin and $40 \mathrm{~mL}$ PBS $\left(37^{\circ} \mathrm{C}\right.$, $25 \mathrm{~min}$ ). Digestion was quenched by the addition of $4 \mathrm{~mL}$ of fetal bovine serum (FBS) after which the solution was filtered through a $132 \mu \mathrm{m}$ filter. The solution was then centrifuged three times at $1,200 \mathrm{rpm}$ for 10 minutes. Cells were then cultured in medium supplemented with $10 \%$ FBS, $1 \mu \mathrm{M}$ sodium pyruvate, $10 \mu \mathrm{M}$ glutamine, $1 \mathrm{x}$ non-essential amino acids, $0.1 \%$ dextrose, and 1\% penicillin/streptomycin (Invitrogen). Cells were plated in poly-L-ornithine-coated T75 flasks and cultured for two cycles in medium consisting of $25 \mu \mathrm{M}$ cytosine arabinoside (Sigma-Aldrich). The inclusion of cytosine arabinoside inhibits astrocyte proliferation. To complete experiments, cultures enriched $(\sim 80 \%)$ for neurons were re-trypsinized and plated in poly-L-ornithine coated 96-well plates at a density of 100,000 cells/well. After $24 \mathrm{~h}$, medium was changed to serum-free AIM $\mathrm{V}$ medium. After another $24 \mathrm{~h}$, demeclocycline $(10 \mu \mathrm{M})$ was added to the neurons. Cells were fixed $24 \mathrm{~h}$ after with $4 \%$ paraformaldehyde and stained for MAP-2 (mouse anti-MAP-2 antibody; clone HM-2; Sigma; M4403; 1:1,000) and Hoeschst S769121. Cells were imaged with an ImageXpress ${ }^{\circledR}$ imaging system (Molecular Devices) and quantified using MetaXpress ${ }^{\circledR}$ (Molecular Devices).

\section{Culture of Human BTICs}

BTICs were isolated from resected specimens of patients with glioblastoma $(7,9,26,36)$. We used three BTIC lines derived from glioma patients designated BT012, BT025, and BT048. These lines had different genetic mutations (26) including BT012: EGFR wildtype (wt), p53 wt, PTEN mutant (mt, frameshift in codon 328); BT025: EGFR wt, p53 mt (T125R), PTEN mt (G129R); and BT048: EGFR mt (K294R, G598V), p53 wt, PTEN wt. BT025 and BT048 were employed in the majority of experiments since they were characterized extensively in our previous study $(6-9,26)$. To propagate the lines, BTICs were dissociated and plated into T25 flasks at regular intervals and grown in serum free culture medium supplemented with epidermal growth factor and fibroblast growth factor-2 in 5\% $\mathrm{CO}_{2}$ as described elsewhere $(36,37)$; we refer to this as BTIC medium. The lines with higher passage numbers were checked for stemness and self-renewal property (data not shown). All experiments with human cells or resected brain specimens were conducted with approval from the Conjoint Health Research Ethics Board, University of Calgary, with informed consent from the human subjects.

We documented passage number (denoted by $\mathrm{P}$ ) after thawing a new vial of cells from liquid nitrogen and kept a record of the number of subsequent passaging. Frozen stocks of BTIC cells were made as soon as possible from previously thawed BTIC lines, to avoid cell changes, contamination, etc. for the next set of experiments. Every time a vial (of BTIC line) was thawed, new stocks were made within a week or two of the growing culture. Thus, the BTICs were usually frozen between P2-P3 of a newly thawed culture. We used BTICs (after thawing) from the expanding and/or growing cultures for experiments between P2 and P10. The lines with higher passage numbers (P8P10) were checked for stemness using stemness markers such as nestin, SOX-2 and Musashi-1 by FACS analysis, and by the ability of dissociated single cells to form spheres. Importantly, BTICs were also sent for sequencing at regular intervals to verify the identity of lines (to ascertain their genetic background with the parental line).

\section{Evaluation of BTIC Growth}

For neurosphere assay, BTIC cells $(10,000$ cells/well/100 $\mu 1$ of serum free BTIC medium) were plated into 96 -well plates $(7,26$, 36). The resultant number of spheres above the $60 \mu \mathrm{m}$ diameter cutoff, a convenient parameter to describe growth characteristics, was monitored after $72 \mathrm{~h}$ by photographing multiple fields per well with subsequent image analyses. Where total cell number was documented, the medium containing the BTIC spheres was collected, centrifuged, resuspended in $25 \mu \mathrm{L}$ of Accumax ${ }^{\mathrm{TM}}$, mixed with Trypan Blue (1:1) and counted using a TC20 $0^{\mathrm{TM}}$ automated cell counter (Bio-Rad).

An alamarBlue ${ }^{\circledR}$ assay was also used to evaluate growth. At predetermined times, alamarBlue ${ }^{\circledR}$ dye (1:10, Life Technologies) was added to each well of cells for $4-6 \mathrm{~h}$ after which readings were taken with a Spectra Max Gemini XS (emission wavelength $=590 \mathrm{~nm}$, excitation wavelength $=544 \mathrm{~nm}$; Molecular Devices). Finally, annexin V-propidium iodide staining was carried out and analyzed using FACS as described before (26).

\section{Drugs Used}

Demeclocycline hydrochloride, tetracycline hydrochloride, and oxytetracycline hydrochloride stock solutions were prepared (10 mM in DMSO; all chemicals from SigmaAldrich) and diluted immediately prior to treatment of cells. While, demeclocycline was used at 1,5 , and $10 \mu \mathrm{M}$ final concentrations, tetracycline and oxytetracycline were used at $10 \mu \mathrm{M}$ only. All dilutions from stock were done in BTIC medium.

\section{Microarray and Bioinformatics}

BTICs (BT012, BT025, and BT048) were treated with $10 \mu \mathrm{M}$ demeclocycline for $6 \mathrm{~h}$. RNA was then extracted using a mirVana 
miRNA Isolation Kit (Ambion, Austin, USA) according to the manufacturer's protocol. Total RNA was purified with RNeasy Plus Micro Kit (Qiagen, Valencia, USA) to remove genomic DNA. The RNA quality of integrity number (RIN) was measured with Agilent RNA Nano Chips on 2,100 Bioanalyzer (Agilent Technologies, Santa Clara, USA). The total of $250 \mathrm{ng}$ of RNA for each sample with RIN higher than 9 was labeled with WT Express Kit (Ambion) and hybridized to Affymetrix GeneChip Human Gene 2.0 ST Array at $45^{\circ} \mathrm{C}$ for $16 \mathrm{~h}$. Arrays were stained and washed on Affymetrix GeneChip Fluidics_450 following manufacturer's protocol and scanned with Affymetrix GeneChip Scanner 3,000 $7 \mathrm{G}$ System.

For data analysis, array data files were generated with GeneChip ${ }^{\circledR}$ Command Console ${ }^{\circledR}$ Software (AGCC) and statistical analyses were carried out in GeneSpring ${ }^{\mathrm{TM}}$ (Agilent Technologies). The fold change between treatment and control was based on the $p<0.05$ from Ttest of unpaired samples.

\section{Statistical Analyses}

The one-way ANOVA with post-hoc Tukey's comparisons was used for multiple group comparisons unless otherwise mentioned, while the $t$-test was used for comparisons of two groups. We used GraphPad Prism software for statistical analysis.

\section{RESULTS}

\section{Demeclocycline Promotes the Activity of Monocytes and Macrophages and Is Not Toxic to Neurons}

While we identified meclocycline as an activator of microglia (33), it was necessary to confirm that its better tolerated derivative, demeclocycline, also has such activity. We first carried out some preliminary studies with mouse bone marrow derived macrophages (BMDM). Notably, demeclocycline alone did not induce mouse macrophages to increase TNF- $\alpha$ production; however, when combined with LPS, demeclocycline further promoted the production of TNF- $\alpha$ (Figure 1A). Moreover, as another index of activity, demeclocycline promoted the chemotaxis (Figure 1B) of stimulated macrophages when combined with LPS.

To corroborate the above findings of mouse cells, we evaluated whether human cells were responsive to demeclocycline. We investigated monocytes isolated from healthy human donors, as these cells would be exposed to demeclocycline in the circulation after systemic administration and could then traffic into the glioma microenvironment as macrophages. We found that human monocytes under basal conditions did not elevate their production of TNF- $\alpha$, an index of

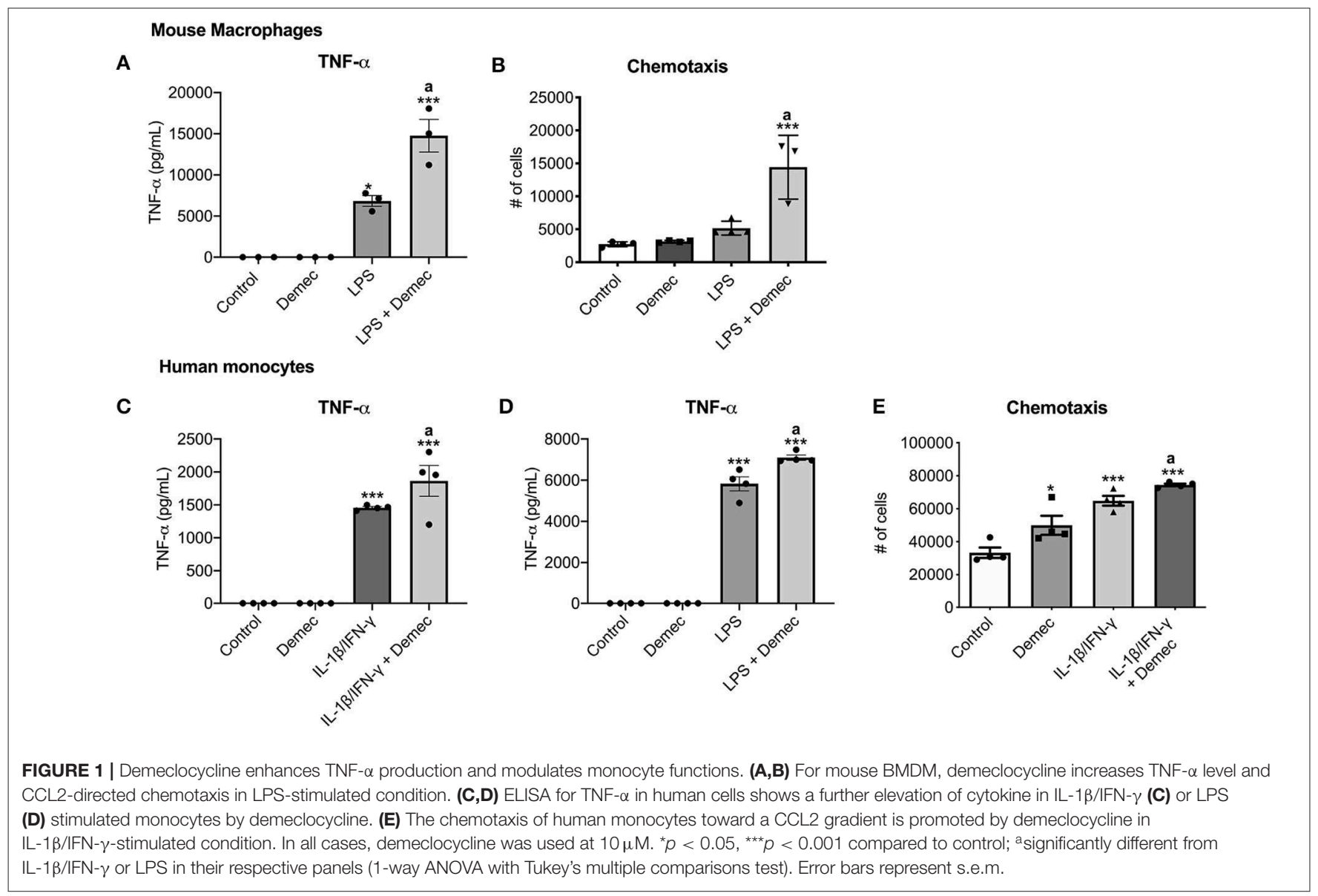


activity, in the presence of demeclocycline alone. However, when human monocytes were exposed to IL1 $\beta /$ IFN- $\gamma$ (Figure 1C), cytokines that are elevated in glioma subjects (38), or to the toll-like receptor-4 ligand LPS (Figure 1D), demeclocycline elicited a further increase in TNF- $\alpha$ levels in activated cells.

The migration of monocytes to a chemokine source, chemotaxis, constitutes another index of cellular activity. In IL$1 \beta / \mathrm{IFN}-\gamma$-primed conditions, we noted that demeclocycline promoted the chemotaxis of human monocytes to CCL2 (Figure 1E); alone, demeclocycline had some enhancing activity.

\section{Demeclocycline-Treated Monocytes Reduce BTIC Growth}

Our previous study (26) found that the capacity of microglia, monocytes and macrophages to reduce BTIC growth could be elicited through the conditioned medium of these cells. Thus, monocytes were isolated from the peripheral venous blood of healthy volunteers and conditioned media were generated (Figure 2A). To determine the capacity of demeclocycline as a novel stimulator of innate immunity to reduce BTIC growth, BTIC lines plated at 10,000 cells per well in 96-well plates were exposed to conditioned medium from untreated monocytes (MonoCM) or to the conditioned medium of monocytes
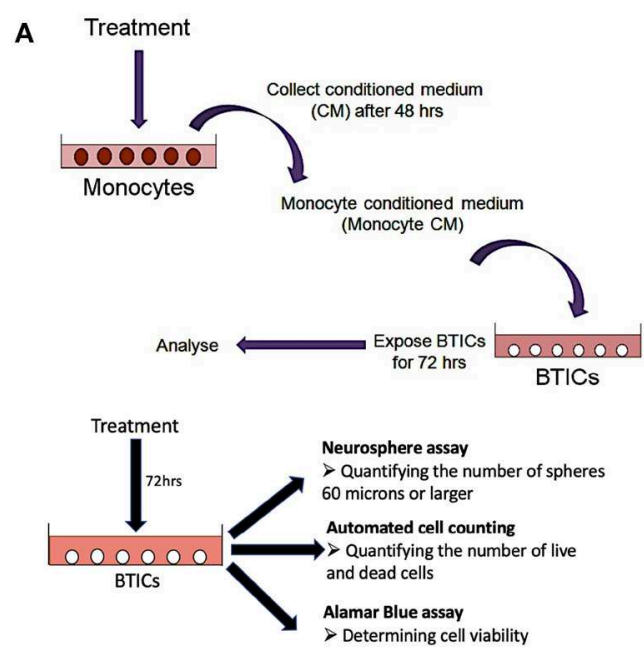

B

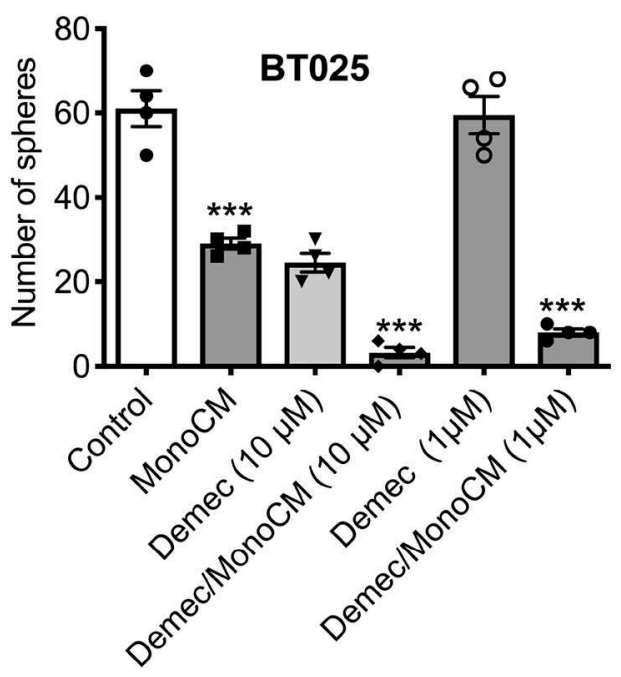

D

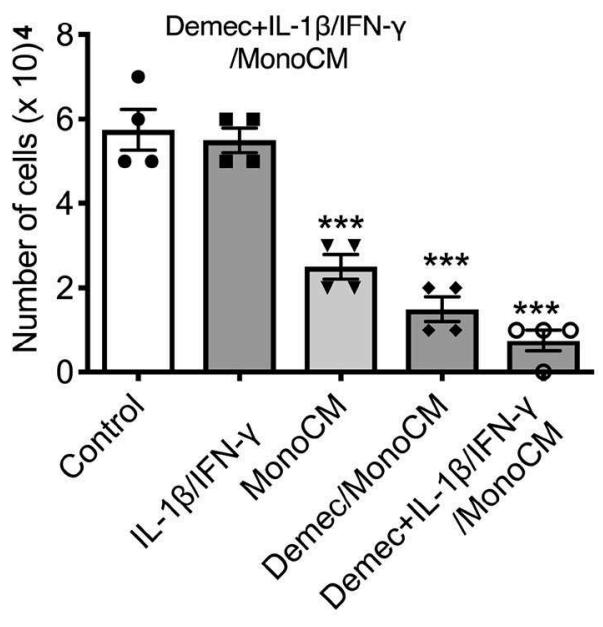

C

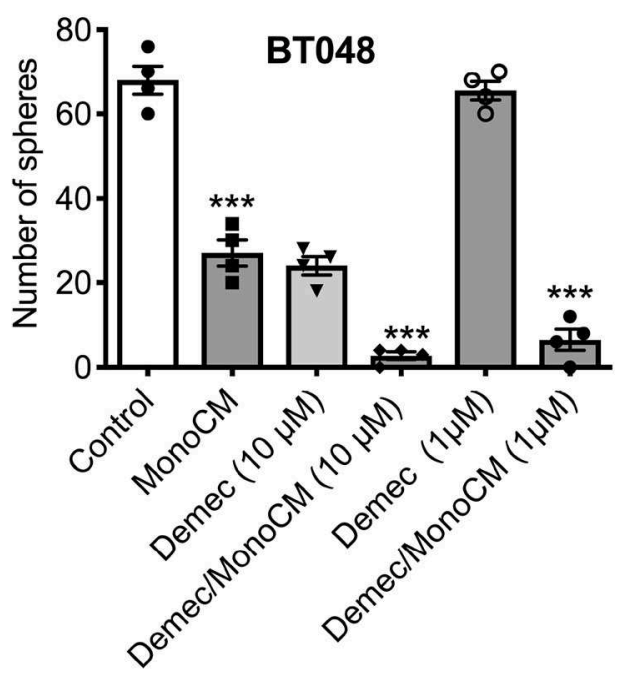

FIGURE 2 | Demeclocycline activated monocytes reduces BTIC growth in culture. (A) Generation of monocyte-conditioned media. (B,C) Untreated human monocytes (MonoCM) or monocytes exposed to demeclocycline (Demec/MonoCM) attenuate BTIC growth compared to basal control after $72 \mathrm{~h}$ as measured through neurosphere assay. Although demeclocycline alone reduced the BTIC growth at $10 \mu \mathrm{M}$, it was ineffective at $1 \mu \mathrm{M}$ in both lines. Notably, Demec/MonoCM had robust effect on BT025 and BT048 cells, and was significantly greater than that of either MonoCM or demeclocycline alone. (D) Demec/MonoCM also reduced the total cell

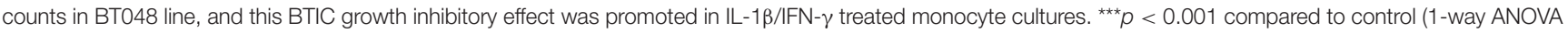
with Tukey's multiple comparisons); $n=4$ for all groups. Error bars represent s.e.m. 
exposed for $48 \mathrm{~h}$ to $10 \mu \mathrm{M}$ demeclocycline (Demec/MonoCM). Reproducing previous results (26), MonoCM reduced the growth of the BT025 and BT048 lines (Figures 2B,C) in sphere-forming assays; importantly, Demec/MonoCM decreased the growth of BTICs further (Figures 2B,C) and there was an additional effect on reducing BTIC growth when conditioned medium from monocytes exposed to both demeclocycline and IL-1 $\beta /$ IFN- $\gamma$ (Demec + IL-1 $\beta /$ IFN- $\gamma /$ MonoCM) was used (Figure 2D).

In these experiments, we noted that demeclocycline $(10 \mu \mathrm{M})$ added directly to BTICs in the absence of monocyte intermediary was sufficient to reduce BTIC growth, suggesting that the medication may affect BTICs in 2 ways: through monocyte intermediary and directly on BTICs.

\section{Demeclocycline Directly Affects the Growth of BTICs}

Because the above results suggest that demeclocycline alone reduced BTIC growth, we sought to investigate its direct role further. We subjected BTICs to different concentrations of demeclocycline and found that 5 and $10 \mu \mathrm{M}$ decreased sphere formation and cell number (Figures 3A,B); an effect on BTIC could be documented for $1 \mu \mathrm{M}$ demeclocycline using the alamarBlue ${ }^{\circledR}$ assay (Figure 3C). Notably, demeclocycline at $10 \mu \mathrm{M}$ concentration had selective efficacy on BTICs as it was without obvious toxicity to non-transformed CNS cells such as microtubule associated protein-2 (MAP-2) labeled neurons (Figures 3D,E).

As the above experiments involved the treatment of freshly dissociated BTIC lines with demeclocycline to determine whether the medication reduced sphere formation and other indices of BTIC growth, we next addressed whether demeclocycline affected BTIC spheres that were already well-formed. We found that when demeclocycline $(10 \mu \mathrm{M})$ was added to growing spheres 3 days after their formation from singly dissociated cells, the drug still reduced the further growth of spheres of the BT025 and BT048 lines (Figures 3F-H).

Overall, our results suggest that demeclocycline can control BTIC growth in two ways: using monocytes as an intermediary, and directly by affecting the proliferation and sphere-forming capacity of BTICs.
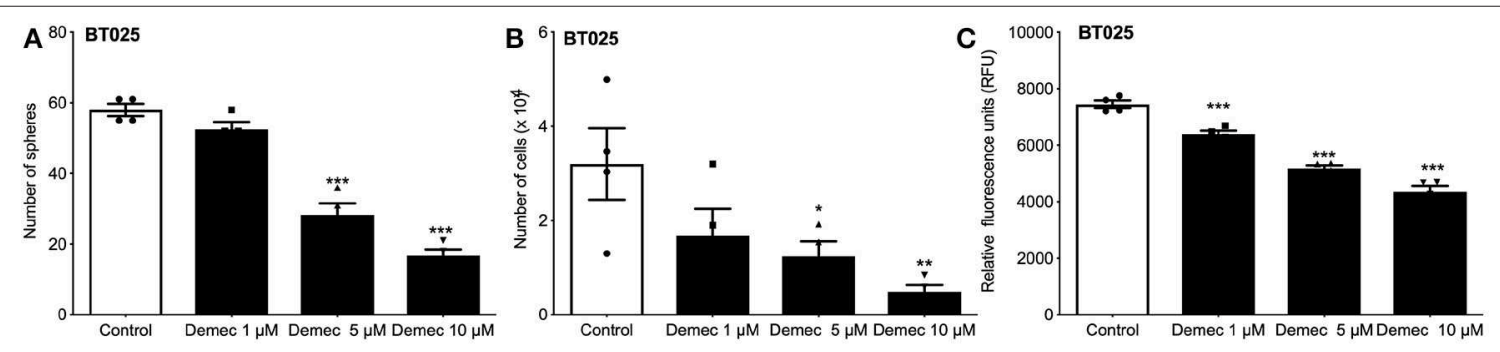

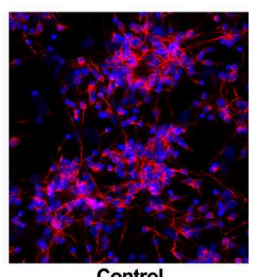

$\mathbf{F}$

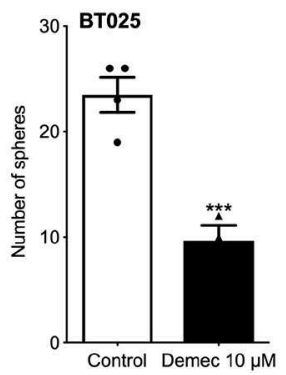

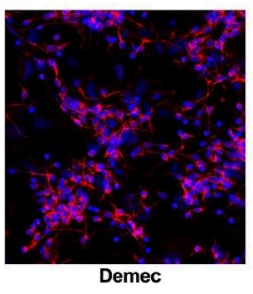

G

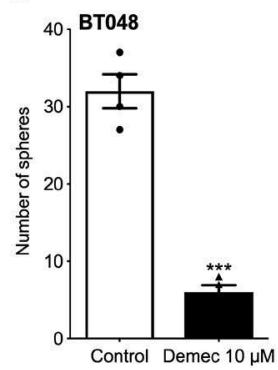

E

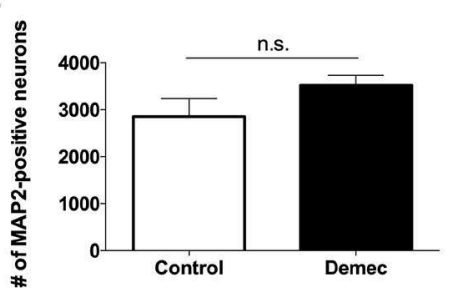

H
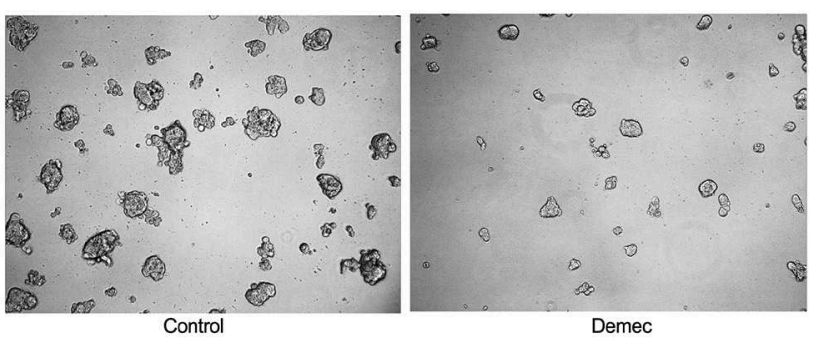

FIGURE 3 | Demeclocycline has a direct impact on BTIC growth reduction. (A-C) Treatment of BT025 with varying concentrations of demeclocycline reduced BTIC growth in culture as evident by reduced sphere formation (A), total number of cells (B), and alamarBlue ${ }^{\circledR}$ assay (C). Results are reproduced with BT048 (data not shown). Error bars represent s.e.m. ${ }^{\star} p<0.05,{ }^{* *} p<0.01,{ }^{\star * *} p<0.001$ compared to controls (1-way ANOVA with Tukey's multiple comparisons test). (D,E) Representative images of MAP2-positive neurons untreated or treated with demeclocycline, and quantification of MAP2-positive neurons demonstrates that demeclocycline was not toxic to human neurons. (F,G) Demeclocycline reduced the number of spheres above the $60 \mu \mathrm{m}$ cutoff when applied to growing spheres 3 days after their formation from singly dissociated cells. Error bars represent s.e.m ( $n$ of 4$) .{ }^{* * *} p<0.001$ (two-tailed Student's $t$-test). (H) Representative images showing reduced sphere size in demeclocycline-treated BTICs (BT048) compared to control at 5 days. 


\section{Mechanisms of Demeclocycline-Mediated BTIC Growth Reduction}

We sought to obtain insights into the mechanisms by which demeclocycline directly reduces BTIC growth. We subjected 3 BTIC lines to microarray analyses and identified 301 genes ( with a cutoff fold change $=1.3$ ) amongst the three lines that were commonly affected by demeclocycline treatment compared to controls (Figure 4A and Supplementary Table 1) (GEO accession number GSE81515). Analysis of the array data using gene-ontology criteria with Panther Classification System bioinformatics software identified several genes that were up or down regulated with demeclocycline treatment (Figure 4B and Supplementary Figure 1). Notably, we found a number of genes known to be involved in glioma progression, invasiveness, signaling or cancer progression that were down regulated by demeclocycline. These include transforming growth factor $\beta 1$ induced transcript 1 protein (TGFB1I1) (39), frizzled class receptor 5 (FZD5) (40), epidermal growth factor modulecontaining mucin-like receptor 2 (EMR2) (41), reactive oxygen species modulator 1 (ROMO1) (42) and B cell lymphoma
3 protein (BCL3) (43) (Figure 4C). In contrast, genes that negatively regulate notch signaling, mTOR activity or AKT such as ChaC Glutathione Specific Gamma-Glutamylcyclotransferase 1 (CHAC1), DNA Damage Inducible Transcript 4 (DDIT4) and C-Type Lectin Domain Family 2 Member A (CLEC2A) were up regulated. With demeclocycline treatment in three BTIC lines (Figure 4C). Notably, a recent study has identified that temozolomide and radiotherapy could induce DDIT4 and repressed mTORC1 activity in some glioblastoma cell lines (44). Thus, overexpression of DDIT4 by demeclocycline in BTIC could be beneficial for glioblastoma patients. Interestingly, when we interrogated glioblastoma databases we found that elevated level of DDIT4 expression was associated with the longevity of glioma patients (Figure 5).

\section{Comparisons of Demeclocycline With Other Tetracyclines on BTIC Growth in vitro}

We compared two other tetracyclines (tetracycline and oxytetracycline) to demeclocycline. We subjected three BTIC lines generated from glioblastoma patients with divergent genetic

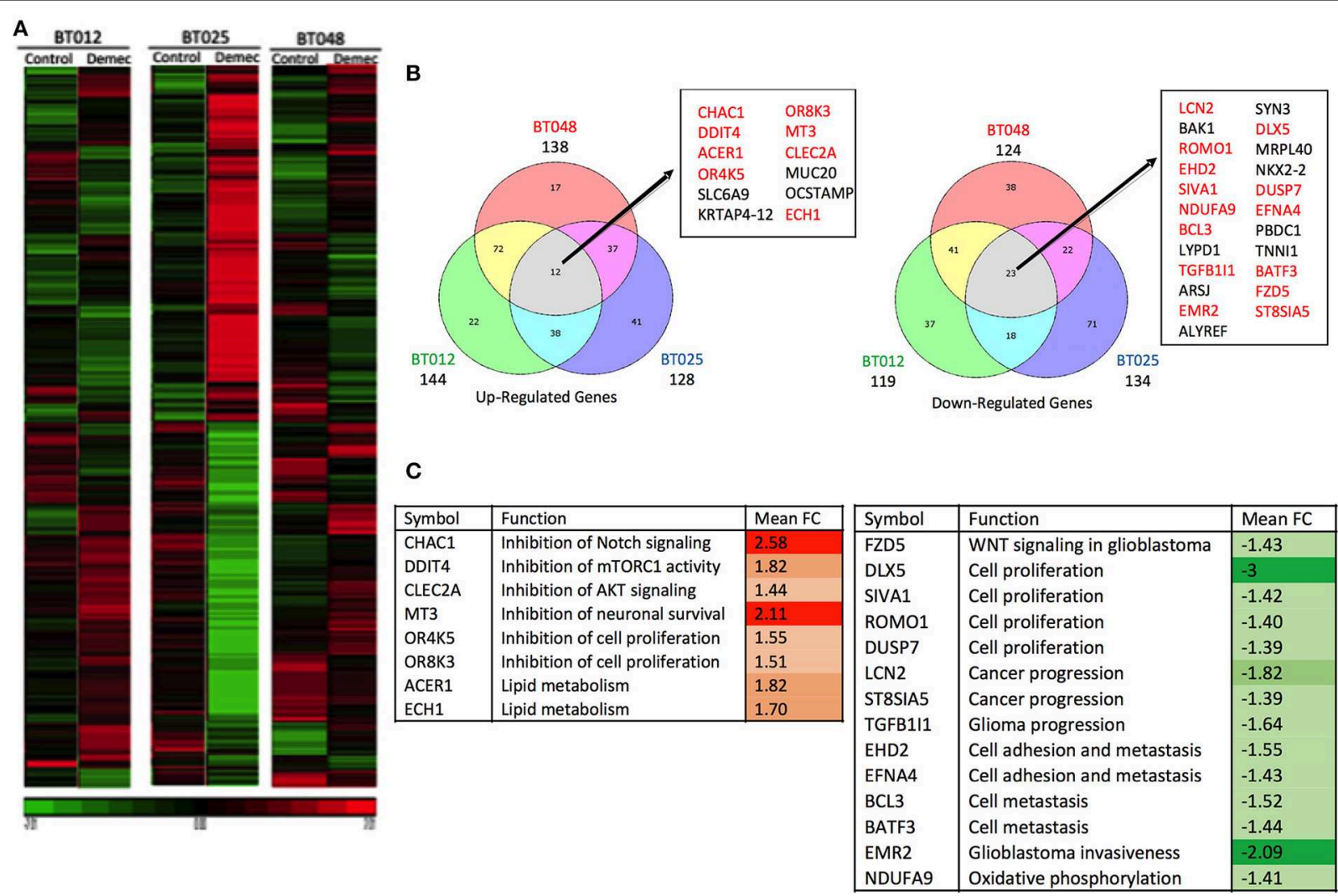

FIGURE 4 | Microarray analyses of BTICs exposed to demeclocycline. (A) Heat map depicting patterns of changing gene expression in three genetically divergent glioblastoma patient-derived BTIC lines after $6 \mathrm{~h}$ of demeclocycline treatment, compared to respective controls; red represents elevation while green displays genes that are reduced by demeclocycline (GEO accession number GSE81515). (B) Venn diagrams comparing up-regulated (fold change, FC $\geq 1.3$ ) and downregulated $(F C \leq-1.3)$ genes in the three BTIC lines following treatment with demeclocycline. Genes intersecting in all 3 sets are noted in box; genes which may be involved in tumor progression are represented in red. Diagrams are generated by Bioinformatics.lu software. (C) Genes with possible role in tumor progression are shown. Up-regulated genes (relative to untreated cells) are represented in red; down-regulated genes (relative to untreated cells) are represented in green. Mean fold change (FC) is calculated for the three BTIC lines following treatment with demeclocycline vs. no treatment. The intensity of the colors represents the strength of the gene deregulation. 
mutations, using demeclocycline as a positive control. Growth was assessed at $72 \mathrm{~h}$ after plating 10,000 cells/well in 96-well plate, using $10 \mu \mathrm{M}$ of each drug. Figure 6A shows that while tetracycline and oxytetracycline reduced the sphere-forming capacity of BTICs to varying extents across different lines, demeclocycline inhibited the sphere-forming capacity of BTICs consistently across all lines. These results were corroborated by alamarBlue ${ }^{\circledR}$ assays (Figure 6B) and cell counts (data not shown).

\section{DISCUSSION}

Tumorigenesis not only alters the surrounding microenvironment, but is regulated by it $(45,46)$. Unfortunately, immune cells in the high grade glioblastoma (GBM) microenvironment generally assume tumor-promoting roles (47-51). Under the influence of GBM, microglia/macrophages are immunosuppressed and may even contribute to GBM invasion (52-54). BTICs are thought to help enforce immunosuppression $(11,12,55-58)$. Thus, we have sought to sway the microglia/macrophage interaction with BTICs toward an anti-tumor phenotype. Via a drug screen of currently available medications, we discovered that amphotericin B could activate blood-derived monocytes to suppress BTIC proliferation and induce differentiation (26). However, amphotericin B is unlikely to be used as an immunostimulator for intracranial disease because of its substantial toxicity at high doses (59). Our attention turned to another drug found on the screen, meclocycline, and its more clinically attractive derivative, demeclocycline.

Demeclocycline is clinically attractive for several reasons. It has already been used for the treatment of bacterial infections and as a treatment for the syndrome of inappropriate antidiuretic hormone (SIADH) in humans $(60,61)$. A recent study showed that demeclocycline was also a promising contrast agent for the intraoperative detection of brain tumors (62). Moreover, when we exposed neural cells to demeclocycline, no significant toxicity was noted. Hence, its application as a drug to treat intracranial disease such as glioblastoma is more conceivable than with amphotericin B or meclocycline.

We first characterized the in vitro ability of demeclocycline to activate monocytes as these cells in the circulation could enter a glioma tumor to become macrophages (63). Thus, exposure of monocytes to an immunostimulator could theoretically result from systemic administration of a drug such as demeclocycline. Alone, demeclocycline did not increase TNF- $\alpha$ secretion by monocytes, a measure of monocyte activity. However, in the presence of primers such as IL- $1 \beta$ and IFN- $\gamma$, cytokines that are
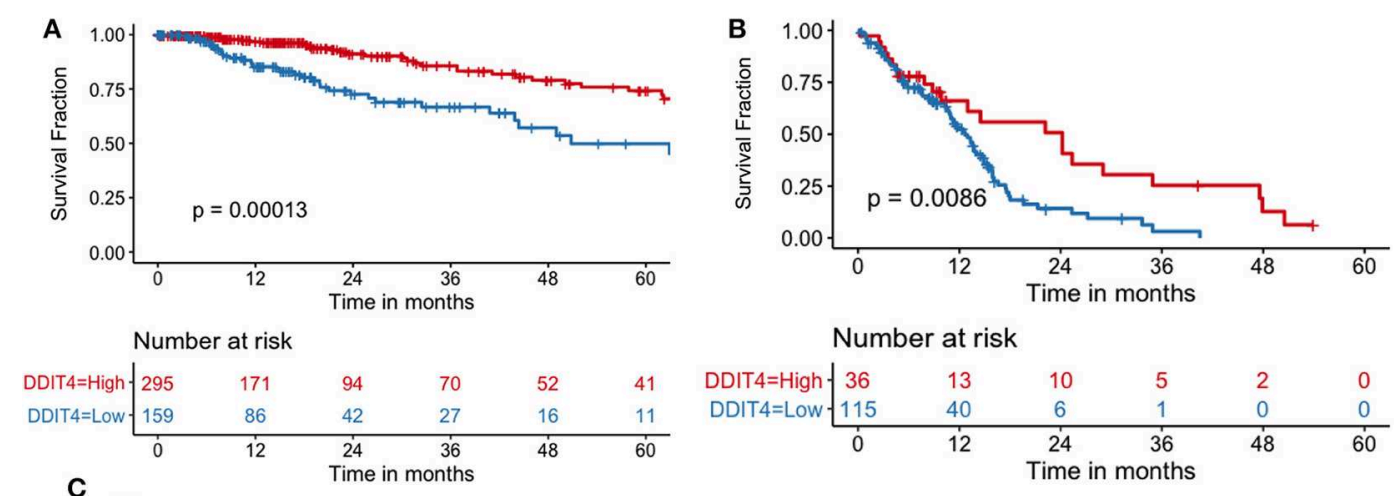

Number at risk
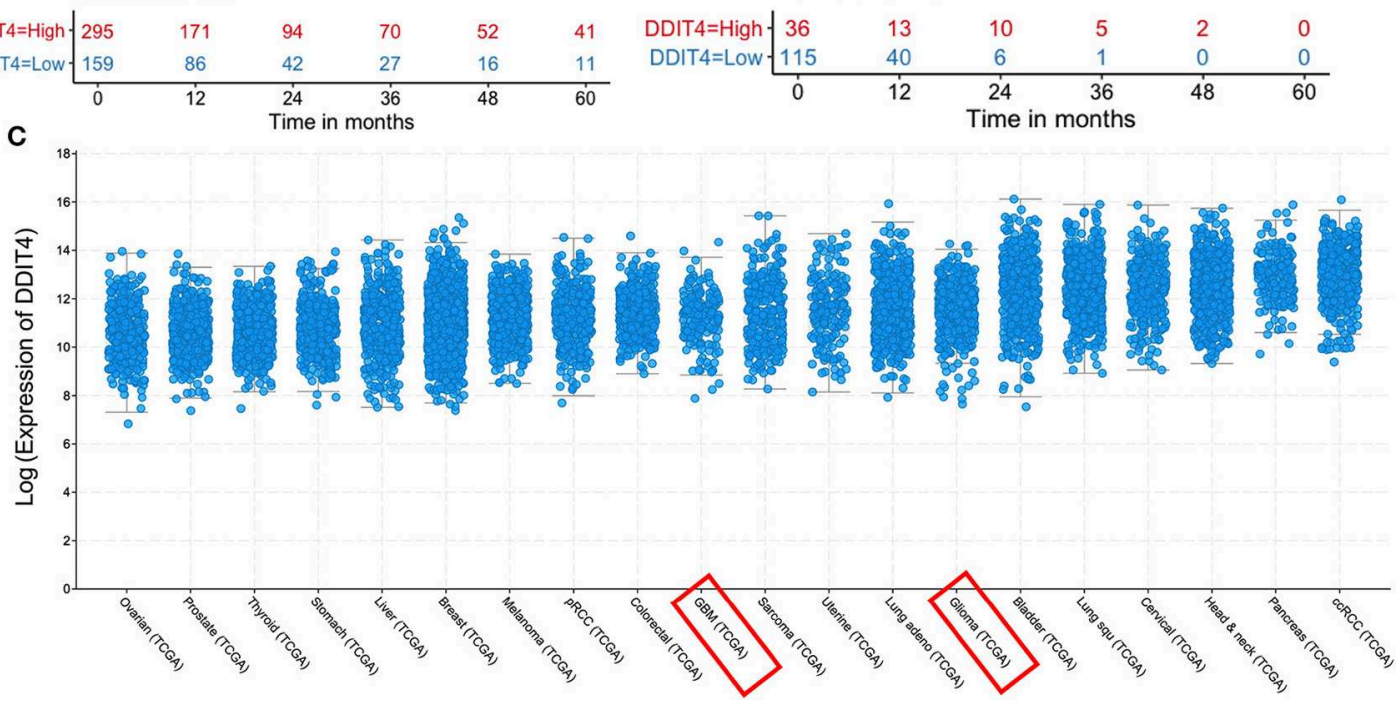

FIGURE 5 | Increased DDIT4 expression is associated with improved survival in gliomas. (A,B) Kaplan-Meier curves showing the association between DDIT4 mRNA expression and overall survival in TCGA (A) low-grade glioma and (B) glioblastoma patients. (C) DDIT4 mRNA expression was plotted across 20 major solid tumor types in TCGA database arranged by increasing median expression (pRCC, Papillary Renal Cell Carcinoma; ccRCC, clear cell renal cell carcinoma; Lung squ, lung squamous cell carcinoma; GBM, glioblastoma). 


\section{A}

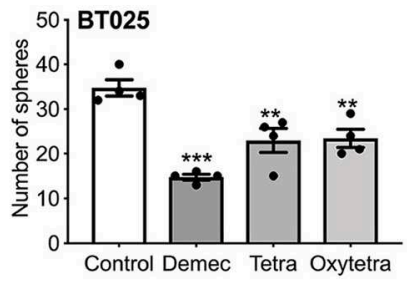

B

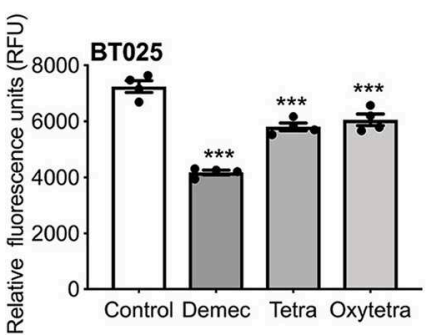

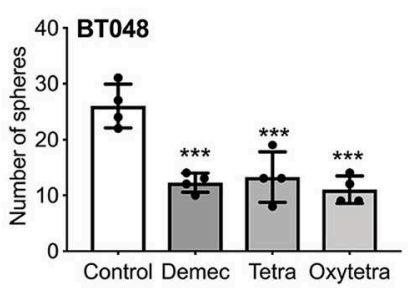
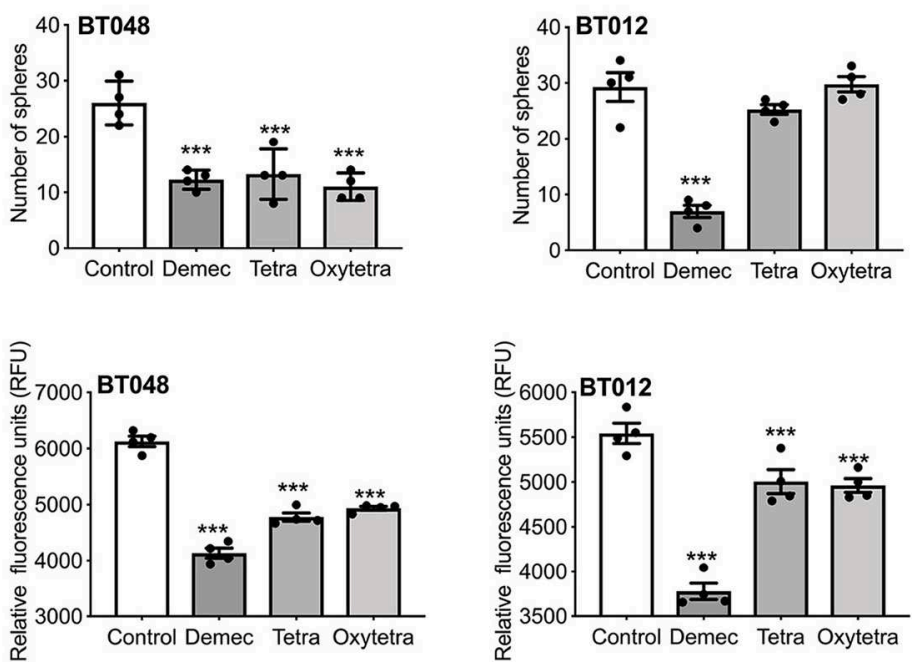

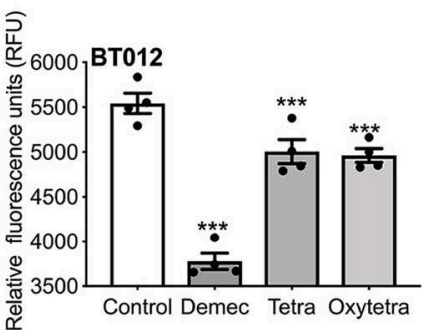

FIGURE 6 | Effects of various tetracyclines on BTIC growth in culture. (A) Three glioblastoma patient-derived BTIC lines were exposed to $10 \mu \mathrm{M}$ each of demeclocycline (demec), tetracycline (tetra) or oxytetracycline (oxytetra). (B) AlamarBlue ${ }^{\circledR}$ assay shows effect of demeclocycline, tetracycline and oxytetracycline on different BTIC lines with divergent genetic mutations, corroborating the reduced sphere-forming capacity of BTICs to varying extents across different lines. ${ }^{\star \star} p<0.01$, ${ }^{* \star *} p<0.001$ compared to control (1-way ANOVA with Tukey's multiple comparisons). Error bars represent s.e.m. ( $n$ of 4).

commonly elevated in glioma patients $(38,64)$, demeclocycline had stimulatory properties beyond that of when either IL1 $\beta$ or IFN- $\gamma$ were administered alone. As confirmation of the immune-stimulatory effect of demeclocycline in the presence of a priming condition, similar results were seen when a conventional stimulator, LPS, was added. Also, the promotion of migration in demeclocyclineexposed monocytes supported the notion that this drug was an activator. To verify these results, the experiments were recapitulated with mouse macrophages. As another measure of the immunestimulatory capacity of demeclocycline, it was shown that conditioned medium collected from monocytes exposed to demeclocycline even in the absence of stimulators could decrease BTIC sphere formation. Given that temozolomide is the frontline chemotherapy for glioblastoma, this adds to the promise of demeclocycline as an additional treatment modality in glioblastoma.

Importantly, demeclocycline is not only an immunestimulator, but can independently decrease BTIC viability, as indicated by alamarBlue and sphere formation assays. As with present treatments, subgroups of glioblastoma patients will be more sensitive to certain treatments based on factors such as genetics and previous treatments $(65,66)$, which may be true of the cell lines derived from those tumors.

To elucidate the mechanisms behind BTIC inhibition by demeclocycline, we employed a microarray analysis. This analysis has implicated several genes known to be involved in glioma or cancer progression (i.e., proliferation, invasion, metastasis) such as TGFB1II (39), FZD5 (40), EMR2 (41), ROMO1 (42), and BCL3 (43) which were significantly down-regulated with demeclocycline treatment in three BTIC lines (Figure 4). On the contrary, genes that negatively regulate Notch signaling, ATK signaling or mTOR activity, such as CHAC1, DDIT4, CLEC2A, were up regulated with demeclocycline treatment across all three BTIC lines (Figure 4). Taken together, these results support the use of demeclocycline as an anti-GBM treatment alone, or as an immunostimulatory agent acting on monocytes and macrophages, and potentially microglia if demeclocycline gains entry into the CNS.

In summary, we have identified a novel, potentially clinically compatible stimulator of monocytes that also has direct inhibitory actions on BTICs. This study has served as the basis for future work in which we will determine the safety and efficacy of demeclocycline in preclinical investigations, with the hopes to expand its use into humans.

\section{DATA AVAILABILITY STATEMENT}

The datasets generated for this study can be found in the GEO accession number GSE81515.

\section{ETHICS STATEMENT}

All experiments with human cells or resected brain specimens were conducted with approval from the Conjoint Health Research Ethics Board, University of Calgary, with written informed consent from the human subjects.

\section{AUTHOR CONTRIBUTIONS}

SS, YL, and RM provided data for the response of BTICs to demeclocycline, other tetracyclines, and monocyte conditioned media. KR, CP, and JW provided data of the response of myeloid cells to demeclocycline. $\mathrm{MK}$ and $\mathrm{PB}$ conducted the bioinformatics and interrogation of databases. SS and VY oversaw the entire project and completed the editing of the manuscript after input from all co-authors. 


\section{FUNDING}

This work was supported by operating grants from the Canadian Institutes of Health Research and from Alberta Innovates-Health Solutions in collaboration with the Alberta Cancer Foundation.

\section{ACKNOWLEDGMENTS}

We acknowledge the technical help of Claudia Silva, Yan Fan, Xiuling Wang, and Fiona Yong. We thank the University of Calgary BTIC Core headed by Drs. Sam Weiss and Greg Cairncross for isolating BTIC lines from patient-resected specimens. We acknowledge the Microarray Facility at the Southern Alberta Cancer Research Institute (SACRI). KR was supported by a Vanier Canada Graduate Scholarship and a

\section{REFERENCES}

1. Stupp R, Mason WP, van den Bent MJ, Weller M, Fisher B, Taphoorn MJ, et al. Radiotherapy plus concomitant and adjuvant temozolomide for glioblastoma. N Engl J Med. (2005) 352:987-96. doi: 10.1056/NEJMoa043330

2. Zeng T, Cui D, Gao L. Glioma: an overview of current classifications, characteristics, molecular biology and target therapies. Front Biosci. (2015) 20:1104-15. doi: 10.2741/4362

3. Cantrell JN, Waddle MR, Rotman M, Peterson JL, Ruiz-Garcia H, Heckman MG, et al. Progress toward long-term survivors of glioblastoma. Mayo Clin Proc. (2019) 94:1278-86. doi: 10.1016/j.mayocp.2018.11.031

4. Singh SK, Hawkins C, Clarke ID, Squire JA, Bayani J, Hide T, et al. Identification of human brain tumour initiating cells. Nature. (2004) 432:396401. doi: $10.1038 /$ nature 03128

5. Cusulin C, Chesnelong C, Bose P, Bilenky M, Kopciuk K, Chan JA, et al. Precursor states of brain tumor initiating cell lines are predictive of survival in xenografts and associated with glioblastoma subtypes. Stem Cell Rep. (2015) 5:1-9. doi: 10.1016/j.stemcr.2015.05.010

6. Sarkar S, Zemp FJ, Senger D, Robbins SM, Yong VW. ADAM-9 is a novel mediator of tenascin-C-stimulated invasiveness of brain tumor-initiating cells. Neuro Oncol. (2015) 17:1095-105. doi: 10.1093/neuonc/nou362

7. Sarkar S, Mirzaei R, Zemp FJ, Wei W, Senger DL, Robbins SM, et al. Activation of NOTCH signaling by tenascin-c promotes growth of human brain tumor-initiating cells. Cancer Res. (2017) 77:323143. doi: 10.1158/0008-5472.CAN-16-2171

8. Mirzaei R, Sarkar S, Dzikowski L, Rawji KS, Khan L, Faissner A, et al. Brain tumor-initiating cells export tenascin-C associated with exosomes to suppress $\mathrm{T}$ cell activity. Oncoimmunology. (2018) 7:e1478647. doi: 10.1080/2162402X.2018.1478647

9. Shen Y, Grisdale CJ, Islam SA, Bose P, Lever J, Zhao EY, et al. Comprehensive genomic profiling of glioblastoma tumors, BTICs, and xenografts reveals stability and adaptation to growth environments. Proc Natl Acad Sci USA. (2019) 116:19098-108. doi: 10.1073/pnas.1813495116

10. Chen J, Li Y, Yu TS, McKay RM, Burns DK, Kernie SG, et al. A restricted cell population propagates glioblastoma growth after chemotherapy. Nature. (2012) 488:522-6. doi: 10.1038/nature11287

11. Bao S, Wu Q, McLendon RE, Hao Y, Shi Q, Hjelmeland AB, et al. Glioma stem cells promote radioresistance by preferential activation of the DNA damage response. Nature. (2006) 444:756-60. doi: 10.1038/nature05236

12. Eramo A, Ricci-Vitiani L, Zeuner A, Pallini R, Lotti F, Sette G, et al. Chemotherapy resistance of glioblastoma stem cells. Cell Death Differ. (2006) 13:1238-41. doi: 10.1038/sj.cdd.4401872

13. Charles NA, Holland EC, Gilbertson R, Glass R, Kettenmann H. The brain tumor microenvironment. Glia. (2012) 60:502-14. doi: 10.1002/glia. 21264

14. Poon CC, Sarkar S, Yong VW, Kelly JJP. Glioblastoma-associated microglia and macrophages: targets for therapies to improve prognosis. Brain. (2017) 140:1548-60. doi: 10.1093/brain/aww355 studentship from the University of Calgary Faculty of Medicine. RM received postdoctoral salary support from the University of Calgary's Eyes High Program. VY acknowledges the Canada Research Chair (Tier 1) program in Neuroimmunology.

\section{SUPPLEMENTARY MATERIAL}

The Supplementary Material for this article can be found online at: https://www.frontiersin.org/articles/10.3389/fimmu. 2020.00272/full\#supplementary-material

Table S1 | Dysregulated genes after treatment BTICs with demeclocycline.

Figure S1 | Clustering of dysregulated genes in BTICs after treatment with demeclocycline. Clusters of up-regulated $\mathbf{( A )}$ or down-regulated (B) genes were generated by the PANTHER classification system based on their functions. Up-regulated (C) or down-regulated (D) genes in corresponding categories are listed in the tables. Mean fold change (FC) is calculated for the three BTIC lines following treatment with demeclocycline versus no treatment.

15. Poon CC, Gordon PMK, Liu K, Yang R, Sarkar S, Mirzaei R, et al. Differential microglia and macrophage profiles in human IDH-mutant and -wild type glioblastoma. Oncotarget. (2019) 10:3129-43. doi: 10.18632/oncotarget.26863

16. Tomaszewski W, Sanchez-Perez L, Gajewski TF, Sampson JH. Brain tumor microenvironment and host state: implications for immunotherapy. Clin Cancer Res. (2019) 25:4202-10. doi: 10.1158/1078-0432.CCR-18-1627

17. Hwang SY, Yoo BC, Jung JW, Oh ES, Hwang JS, Shin JA, et al. Induction of glioma apoptosis by microglia-secreted molecules: the role of nitric oxide and cathepsin B. Biochim Biophys Acta. (2009) 1793:165668. doi: 10.1016/j.bbamcr.2009.08.011

18. Chicoine MR, Zahner M, Won EK, Kalra RR, Kitamura T, Perry A, et al. The in vivo antitumoral effects of lipopolysaccharide against glioblastoma multiforme are mediated in part by Toll-like receptor 4. Neurosurgery. (2007) 60:372-80. doi: 10.1227/01.NEU.0000249280.61761.2E

19. Zhou W, Ke SQ, Huang Z, Flavahan W, Fang X, Paul J, et al. Periostin secreted by glioblastoma stem cells recruits M2 tumour-associated macrophages and promotes malignant growth. Nat Cell Biol. (2015) 17:17082. doi: $10.1038 /$ ncb3090

20. Hussain SF, Yang D, Suki D, Aldape K, Grimm E, Heimberger $\mathrm{AB}$. The role of human glioma-infiltrating microglia/macrophages in mediating antitumor immune responses. Neuro Oncol. (2006) 8:261-79. doi: 10.1215/15228517-2006-008

21. Chen X, Zhang L, Zhang IY, Liang J, Wang H, Ouyang M, et al. RAGE expression in tumor-associated macrophages promotes angiogenesis in glioma. Cancer Res. (2014) 74:7285-97. doi: 10.1158/0008-5472.CAN-14-1240

22. Hu F, Dzaye OD, Hahn A, Yu Y, Scavetta RJ, Dittmar G, et al. Glioma-derived versican promotes tumor expansion via glioma-associated microglial/macrophages Toll-like receptor 2 signaling. Neuro Oncol. (2015) 17:200-10. doi: 10.1093/neuonc/nou324

23. Zhai H, Heppner FL, Tsirka SE. Microglia/macrophages promote glioma progression. Glia. (2011) 59:472-85. doi: 10.1002/glia.21117

24. Wu A, Wei J, Kong LY, Wang Y, Priebe W, Qiao W, et al. Glioma cancer stem cells induce immunosuppressive macrophages/microglia. Neuro Oncol. (2010) 12:1113-25. doi: 10.1093/neuonc/noq082

25. Ye XZ, Xu SL, Xin YH, Yu SC, Ping YF, Chen L, et al. Tumorassociated microglia/macrophages enhance the invasion of glioma stemlike cells via TGF-betal signaling pathway. J Immunol. (2012) 189:44453. doi: 10.4049/jimmunol.1103248

26. Sarkar S, Doring A, Zemp FJ, Silva C, Lun X, Wang X, et al. Therapeutic activation of macrophages and microglia to suppress brain tumor-initiating cells. Nat Neurosci. (2014) 17:46-55. doi: 10.1038/nn.3597

27. Saha D, Martuza RL, Rabkin SD. Macrophage polarization contributes to glioblastoma eradication by combination immunovirotherapy and immune checkpoint blockade. Cancer Cell. (2017) 32:253-67 e255. doi: 10.1016/j.ccell.2017.07.006

28. Mukherjee S, Fried A, Hussaini R, White R, Baidoo J, Yalamanchi S, et al Phytosomal curcumin causes natural killer cell-dependent repolarization of glioblastoma (GBM) tumor-associated microglia/macrophages and 
elimination of GBM and GBM stem cells. J Exp Clin Cancer Res. (2018) 37:168. doi: 10.1186/s13046-018-0792-5

29. Prionisti I, Buhler LH, Walker PR, Jolivet RB. Harnessing microglia and macrophages for the treatment of glioblastoma. Front Pharmacol. (2019) 10:506. doi: 10.3389/fphar.2019.00506

30. Kees T, Lohr J, Noack J, Mora R, Gdynia G, Todt G, et al. Microglia isolated from patients with glioma gain antitumor activities on poly (I:C) stimulation. Neuro Oncol. (2012) 14:6478. doi: 10.1093/neuonc/nor182

31. Wang J, Leavenworth JW, Hjelmeland AB, Smith R, Patel N, Borg B, et al. Deletion of the RNA regulator HuR in tumor-associated microglia and macrophages stimulates anti-tumor immunity and attenuates glioma growth. Glia. (2019) 67:2424-39. doi: 10.1002/glia.23696

32. Laniado-Laborin R, Cabrales-Vargas MN. Amphotericin B: side effects and toxicity. Rev Iberoam Micol. (2009) 26:223-7. doi: 10.1016/j.riam.2009.06.003

33. Samanani S, Mishra M, Silva C, Verhaeghe B, Wang J, Tong J, et al. Screening for inhibitors of microglia to reduce neuroinflammation. CNS Neurol Disord Drug Targets. (2013) 12:741749. doi: 10.2174/18715273113126660177

34. Sherlock M, Thompson CJ. The syndrome of inappropriate antidiuretic hormone: current and future management options. Eur J Endocrinol. (2010) 62(Suppl. 1):S13-18. doi: 10.1530/EJE-09-1057

35. Doring A, Sloka S, Lau L, Mishra M, van Minnen J, Zhang X, et al. Stimulation of monocytes, macrophages, and microglia by amphotericin B and macrophage colony-stimulating factor promotes remyelination. $J$ Neurosci. (2015) 35:1136-48. doi: 10.1523/JNEUROSCI.1797-14.2015

36. Kelly JJ, Stechishin O, Chojnacki A, Lun X, Sun B, Senger DL, et al. Proliferation of human glioblastoma stem cells occurs independently of exogenous mitogens. Stem Cells. (2009) 27:1722-33. doi: 10.1002/stem.98

37. Zemp FJ, Lun X, McKenzie BA, Zhou H, Maxwell L, Sun B, et al. Treating brain tumor-initiating cells using a combination of myxoma virus and rapamycin. Neuro Oncol. (2013) 15:904-20. doi: 10.1093/neuonc/not035

38. Cuny E, Loiseau H, Penchet G, Ellie E, Arsaut J, Vital A, et al. Association of elevated glial expression of interleukin-1beta with improved survival in patients with glioblastomas multiforme. J Neurosurg. (2002) 96:294301. doi: $10.3171 /$ jns.2002.96.2.0294

39. Liu Y, Hu H, Wang K, Zhang C, Wang Y, Yao K, et al. Multidimensional analysis of gene expression reveals TGFB1I1-induced EMT contributes to malignant progression of astrocytomas. Oncotarget. (2014) 5:12593606. doi: $10.18632 /$ oncotarget. 2518

40. Lee Y, Lee JK, Ahn SH, Lee J, Nam DH. WNT signaling in glioblastoma and therapeutic opportunities. Lab Invest. (2016) 96:137-50. doi: 10.1038/labinvest.2015.140

41. Rutkowski MJ, Sughrue ME, Kane AJ, Kim JM, Bloch O, Parsa AT. Epidermal growth factor module-containing mucin-like receptor 2 is a newly identified adhesion $\mathrm{G}$ protein-coupled receptor associated with poor overall survival and an invasive phenotype in glioblastoma. J Neurooncol. (2011) 105:16571. doi: 10.1007/s11060-011-0576-7

42. Yu MO, Song NH, Park KJ, Park DH, Kim SH, Chae YS, et al. Romol is associated with ROS production and cellular growth in human gliomas. $J$ Neurooncol. (2015) 121:7381. doi: 10.1007/s11060-014-1608-x

43. Maldonado V, Melendez-Zajgla J. Role of Bcl-3 in solid tumors. Mol Cancer. (2011) 10:152. doi: 10.1186/1476-4598-10-152

44. Foltyn M, Luger AL, Lorenz NI, Sauer B, Mittelbronn M, Harter $\mathrm{PN}$, et al. The physiological mTOR complex 1 inhibitor DDIT4 mediates therapy resistance in glioblastoma. Br J Cancer. (2019) 120:481-7. doi: 10.1038/s41416-018-0368-3

45. Wang $\mathrm{Q}, \mathrm{Hu} \mathrm{B}, \mathrm{Hu} \mathrm{X}$, Kim H, Squatrito M, Scarpace L, et al. Tumor evolution of glioma-intrinsic gene expression subtypes associates with immunological changes in the microenvironment. Cancer Cell. (2017) 32:4256 e46. doi: 10.1016/j.ccell.2017.06.003

46. Saha D, Rabkin SD. Immunohistochemistry for tumor-infiltrating immune cells after oncolytic virotherapy. Methods Mol Biol. (2020) 2058:17990. doi: 10.1007/978-1-4939-9794-7_11

47. Coussens LM, Werb Z. Inflammation and cancer. Nature. (2002) 420:8607. doi: $10.1038 /$ nature 01322

48. de Visser KE, Eichten A, Coussens LM. Paradoxical roles of the immune system during cancer development. Nat Rev Cancer. (2006) 6:2437. doi: $10.1038 / \mathrm{nrc} 1782$

49. Ruhrberg C, De Palma M. A double agent in cancer: deciphering macrophage roles in human tumors. Nat Med. (2010) 16:861-2. doi: 10.1038/nm0810-861
50. Chanmee T, Ontong P, Konno K, Itano N. Tumor-associated macrophages as major players in the tumor microenvironment. Cancers. (2014) 6:167090. doi: 10.3390 /cancers6031670

51. Hernandez-SanMiguel E, Gargini R, Cejalvo T, Segura-Collar B, NunezHervada P, Hortiguela R, et al. Ocoxin modulates cancer stem cells and M2 macrophage polarization in glioblastoma. Oxid Med Cell Longev. (2019) 2019:9719730. doi: 10.1155/2019/9719730

52. Charles NA, Holland EC, Gilbertson R, Glass R, Kettenmann H. The brain tumor microenvironment. Glia. (2011) 59:1169-80. doi: 10.1002/glia.21136

53. Ma Q, Long W, Xing C, Chu J, Luo M, Wang HY, et al. Cancer stem cells and immunosuppressive microenvironment in glioma. Front Immunol. (2018) 9:2924. doi: 10.3389/fimmu.2018.02924

54. Jackson CM, Choi J, Lim M. Mechanisms of immunotherapy resistance: lessons from glioblastoma. Nat Immunol. (2019) 20:1100-9. doi: 10.1038/s41590-019-0433-y

55. Blazek ER, Foutch JL, Maki G. Daoy medulloblastoma cells that express $\mathrm{CD} 133$ are radioresistant relative to $\mathrm{CD} 133$ - cells, and the $\mathrm{CD} 133+$ sector is enlarged by hypoxia. Int J Radiat Oncol Biol Phys. (2007) 67:15. doi: 10.1016/j.ijrobp.2006.09.037

56. Ropolo M, Daga A, Griffero F, Foresta M, Casartelli G, Zunino A, et al. Comparative analysis of DNA repair in stem and nonstem glioma cell cultures. Mol Cancer Res. (2009) 7:383-92. doi: 10.1158/1541-7786.MCR08-0409

57. Wang J, Wakeman TP, Lathia JD, Hjelmeland AB, Wang XF, White RR, et al. Notch promotes radioresistance of glioma stem cells. Stem Cells. (2010) 28:17-28. doi: 10.1002/stem.261

58. Riva M, Wouters R, Weerasekera A, Belderbos S, Nittner D, Thal DR, et al. CT2A neurospheres-derived high-grade glioma in mice: a new model to address tumor stem cells and immunosuppression. Biol Open. (2019) 8:bio044552. doi: 10.1242/bio.044552

59. Larsen RA, Bauer M, Thomas AM, Graybill JR. Amphotericin B and fluconazole, a potent combination therapy for cryptococcal meningitis. Antimicrob Agents Chemother. (2004) 48:98591. doi: 10.1128/AAC.48.3.985-991.2004

60. Forrest JNJr, Cox M, Hong C, Morrison G, Bia M, Singer I. Superiority of demeclocycline over lithium in the treatment of chronic syndrome of inappropriate secretion of antidiuretic hormone. N Engl J Med. (1978) 298:173-7. doi: 10.1056/NEJM197801262980401

61. Igaz P, Toth M, Mezody M, Glaz E, Penzes I, Racz K, et al. [Effective demeclocycline therapy in a patient with over-secretion of antidiuretic hormone following head trauma]. Orv Hetil. (1999) 140:2873-5.

62. Wirth D, Smith TW, Moser R, Yaroslavsky AN. Demeclocycline as a contrast agent for detecting brain neoplasms using confocal microscopy. Phys Med Biol. (2015) 60:3003-11. doi: 10.1088/0031-9155/60/7/3003

63. Parney IF, Waldron JS, Parsa AT. Flow cytometry and in vitro analysis of human glioma-associated macrophages. Lab Investig J Neurosurg. (2009) 110:572-82. doi: 10.3171/2008.7.JNS08475

64. Hao C, Parney IF, Roa WH, Turner J, Petruk KC, Ramsay DA. Cytokine and cytokine receptor mRNA expression in human glioblastomas: evidence of Th1, Th2 and Th3 cytokine dysregulation. Acta Neuropathol. (2002) 103:1718. doi: $10.1007 / \mathrm{s} 004010100448$.

65. Ramirez YP, Weatherbee JL, Wheelhouse RT, Ross AH. Glioblastoma multiforme therapy and mechanisms of resistance. Pharmaceuticals. (2013) 6:1475-506. doi: 10.3390/ph6121475

66. Padfield E, Ellis HP, Kurian KM. Current therapeutic advances targeting EGFR and EGFRvIII in glioblastoma. Front Oncol. (2015) 5:5. doi: 10.3389/fonc.2015.00005

Conflict of Interest: The authors declare that the research was conducted in the absence of any commercial or financial relationships that could be construed as a potential conflict of interest.

Copyright $\odot 2020$ Sarkar, Li, Mirzaei, Rawji, Poon, Wang, Kumar, Bose and Yong. This is an open-access article distributed under the terms of the Creative Commons Attribution License (CC BY). The use, distribution or reproduction in other forums is permitted, provided the original author(s) and the copyright owner(s) are credited and that the original publication in this journal is cited, in accordance with accepted academic practice. No use, distribution or reproduction is permitted which does not comply with these terms. 